Vol. 2, No. 1, Desember 2021

\title{
PENDAMPINGAN PENGGUNAAN APLIKASI RT ONLINE
}

\author{
Nurabiah \\ Fakultas Ekonomi dan Bisnis Universitas Mataram \\ nurabiah@unram.ac.id \\ Herlina Pusparini \\ Fakultas Ekonomi dan Bisnis Universitas Mataram \\ h.pusparini@unram.ac.id \\ Nur Fitriyah \\ Fakultas Ekonomi dan Bisnis Universitas Mataram \\ nurftiriyah@unram.ac.id
}

Info Artikel

Diterima:

02-12-2021

Direvisi:

28-12-2021

Diterbitkan:

28-12-2021

\begin{abstract}
Abstrak
Pengabdian ini bertujuan untuk untuk meningkatkan pengetahuan dan keterampilan penggunaan aplikasi Rukun Tetangga secara online pada masyarakat Lingkungan Kesra khususnya RT 01 dan 02 Kelurahan Tanjung Karang Permai Kecamatan Sekarbela Kota Mataram. Untuk pemecahan permasalahan mitra terkait dengan pendampingan penggunaan aplikasi RT online maka pelaksanan pengabdian ini ada dua tahap, antara lain : 1) memberikan pengetahuan tentang aplikasi RT online dengan berbagai kemanfaatannya bagi pengurus RT dan warga sehingga bisa melek dengan aplikasi ini. 2) pendampingan penggunaan aplikasi RT online untuk memudahkan warga dan pengurus RT dalam hal administrasi dan keuangan RT. Sasaran pendampingan penggunaan aplikasi RT online ini pada seluruh warga dan pengurus RT 01 dan 02 lingkungan Kesra Tanjung Karang Permaia Sekarbela Kota Mataram. Pendampingan ini dilaksanakan selama sehari dengan 30 orang peserta. Kegiatan pendampingan ini berjalan dengan lancar. Semua peserta antusias mengikuti acara hingga selesai. Peserta juga menilai bahwa pendampingan ini penting dan sangat diperlukan. Peserta berharap ditindaklanjuti dengan melakukan pendampingan lagi sehingga dapat mengaplikasikan dengan lancar
\end{abstract}

Kata Kunci: pendampingan, aplikasi RT online, RT

DOI: $10.29303 /$ abdimassangkabira.v2i1.78 


\section{Pendahuluan}

Seiring dengan pertumbuhan jumlah penduduk akan berdampak pula pada kehidupan bermasyarakat dan bersosial baik di daerah perkotaan maupun dipedasaan. Kehidupan bermasyarakat pada tingkatan paling bawah diatur oleh Peraturan Pemerintah melalui Pemendagri nomor 5 tahun 2007 yang mengatur tentang Pembentukan Rukun Warga dan Rukun Tetangga. Meskipun ditujukan sebagai lembaga kemasyarakatan, Rukun Tetangga dan Rukun Warga pada hakekatnya dilahirkan untuk membantu berbagai pelaksanaan kegiatan.Peran Rukun Tetangga dalam kehidupan bermasyarakat mempunyai peran yang cukup penting karena sebagai kontrol warga dalam kehidupan bersosial dan bermasyarakat dan membantu pemerintahan di tingkat yang lebih tinggi desa atau kelurahan.

Kelurahan Tanjung Karang Permai lingkungan Kesejahteraan khususnya di RT 01 dan 02 memiliki $60 \mathrm{KK}$ yang rata-rata warganya sebagian adalah pendatang dan dari berbagai macam jenis profesi dan kesibukan warganya masing-masing hal ini tentu perlu kontrol dari ketua RT agar tertib secara kependudukan dan dapat memberikan laporan kepada kelurahan secara cepat, namun pendataan warga selama ini masih dilakukan secara konvensional dicatat dibuku dan tentunya kesulitan dalam pencarian data secara cepat.Begitu juga dengan warga mengurus sesuatu masih datang ke pengurus RT dan belum tentu juga pengurus RT berada di rumah sehingga warga kadang pulang lagi hal ini tentu menjadi kurang maksimal dalam pelayanan terhadap warga.

Melihat perkembangan teknologi saat ini sudah sangat cepat dan tingkat mobilisasi warga yang sibuk dan bahkan dalam kawasan satu RT sesama warga tidak saling kenal hal ini tentu dapat menjadi kurang baik dalam hidup bersosialisasi untuk itu perlu adanya sebuah inovasi agar warga dapat saling kenal satu dengan yang lain walaupun jarang bertemu karena kesibukan warganya melalui aplikasi RT online yang dapat diakses melalui internet ataupun berbasis android. Internet merupakan salah satu dari kecanggihan teknologi informasi dan komunikasi.Dengan menggunakan internet memungkinkan individu memperoleh informasi apapun yang ada dan bertukar informasi tanpa terhambat oleh batas ruang dan waktu (Bariyyah \& Permatasari, 2017).

Banyak aplikasi RT online yang berbasis android, ada yang berbayar da nada yang tidak berbayar. Tetapi kebanyakan aplikasinya berbayar. Aplikasi RT online ini antara lain : 1) RT Pintar 2) RTRWKita 3) Beatcom RTRW Net 4) RUKUN WARGAKU 5) Wargaloka 6) SMART RT/RW 7) Prowarga 8) SIAP RT. Salah satu aplikasi yang tidak berbayar adalah aplikasi Siap RT. Aplikasi Siap RT merupakan aplikasi yang bertujuan untuk membantu mempermudah tugas-tugas rutin pengurus rumah tangga (RT) dalam menata administrasi warga maupun keuangan sehingga lebih transparan. Dari aplikasi ini juga diharapkan dapat memperat hubungan antar warga, menumbuhkan rasa persaudaraan antar warga, saling mengenal, saling peduli, dan saling berbagi informasi dengan warga sekitar khususnya tetangga lingkungannya

Dengan memanfaatkan aplikasi Siap RT ini masyarakat dapat dengan mudah mendapatkan informasi seperti melihat informasi warga yang berada di RT 01 atau 02 ada berapa jumlahnya, status pekerjaan warga dan seterusnya hingga pengurusan 


\section{개 \\ Vol. 2, No. 1, Desember 2021}

surat pengantar dapat dilakukan tanpa harus datang meminta ke pengurus RT dengan mengisi blangko yang diisi oleh pengurus RT, warga dapat mencetak sendiri suratanya dari rumah barulah datang ke pengurus RT untuk meminta pengesahan dan dari sisi pengurus RT dapat dengan mudah mendata warganya dan menyajikan informasi terkait dengan RT secara cepat jika ada pihak-pihak yang meminta data warganya berdasarkan jenis kelamin, umur ataupun status warganya. Oleh karena itu pengabdian ini memberikan pendampingan penggunaan aplikasi "Siap RT" di Lingkungan Kesra RT 01 dan 02

\section{Metode}

Untuk pemecahan permasalahan mitra terkait dengan pendampingan penggunaan aplikasi RT online maka pelaksanan pengabdian ini ada dua tahap, antara lain :

1) Tahap Pertama

Memberikan pengetahuan tentang aplikasi RT online dengan berbagai kemanfaatannya bagi pengurus RT dan warga sehingga bisa melek dengan aplikasi ini.

2) Tahap Kedua

Pendampingan penggunaan aplikasi RT online untuk memudahkan warga dan pengurus RT dalam hal administrasi dan keuangan RT. Pelatihan ini dilaksanakan di salah satu rumah pengurus RT 01 di lingkungan Kesra Perumnas dengan menggunakan HP android masing-masing. Dalam pelatihan ini metodenya ceramah, latihan dan diskusi.

Sasaran pendampingan penggunaan aplikasi RT online ini pada seluruh warga dan pengurus RT 01 dan 02 lingkungan Kesra Tanjung Karang Permaia Sekarbela Kota Mataram. Kenapa warga dan pengurus RT karena aplikasi RT online ini dibuat untuk memudahkan seluruh warga di RT tersebut dan fitur-fiturnya sangat mudah digunakan. Jumlah warga di RT 01 dan 02 di lingkungan Kesra Tanjung Karang Permai sebanyak 60 warga. Dengan harapan minimal setengah dari warga RT 01 dan 02 bisa mengikuti pelatihan ini.

\section{Gambar 1. Contoh Diagram}

(Gambar harus diberikan penomoran, contohnya: Gambar 1. Contoh Diagram. Keterangan gambar (nomor dan judul gambar) diletakkan di tengah bawah)

\section{Hasil}

Hasil kegiatan yang telah dilakukan dalam pengabdian ini adalah sebagai berikut: Tahap Perencanaan Pengabdian

Pada tahap ini, berdasarkan investigasi awal, tim pengabdi menganalisis mengenai kebutuhan-kebutuhan apa yang digunakan dalam pengabdian ini. Karena ini pelatihannnya berupa aplikasi RT online, sehingga dibutuhkan persiapan-persiapan seperti perlengkapan dan peralatan seperti kertas, alat-alat tulis, HP Android, dan laptop. Bahan dan alat yang digunakan adalah sebagai berikut: 
Tahap Pelaksanaan Pengabdian

Pendampingan ini dilaksanakan di salah satu rumah pengabdi di lingkungan Kesra Perumnas dan juga pendamping mendatangi satu-satu pengurus di rumah masing-masing untuk diberikan pendampingan. Pendampingan ini dilaksanakan selama sehari dengan 30 orang warga RT 01 dan 02 yang ada di Lingkungan Kesra. Pengabdian ini dilaksanakan tanggal 15 Oktober 2021. Pengabdian ini menfokuskan pendampingan dalam hal penggunaan aplikasi RT online dengan nama aplikasi "Siap RT". Penggunaan aplikasi ini dari dua sudut pandang yaitu dari ketua RT dan warga RT Tersebut. SIAP RT adalah aplikasi manajemen RT/RW, untuk memudahkan berinterkasi dengan warga setempat. Aplikasi ini meliputi Manajemen Data Warga, Layanan Surat Menyurat, Media Informasi, Laporan Keuangan, Manajemen Voting, Tombol Darurat dan Manajemen Inventaris. Aplikasi SIAP RT adalah aplikasi gratis tanpa biaya langganan dan dapat didownload melalui Aplikasi Play Store pada android kita. Contoh fitur yang tersedia di aplikasi siap RT tersebut bisa dilihat di gambar 1 .
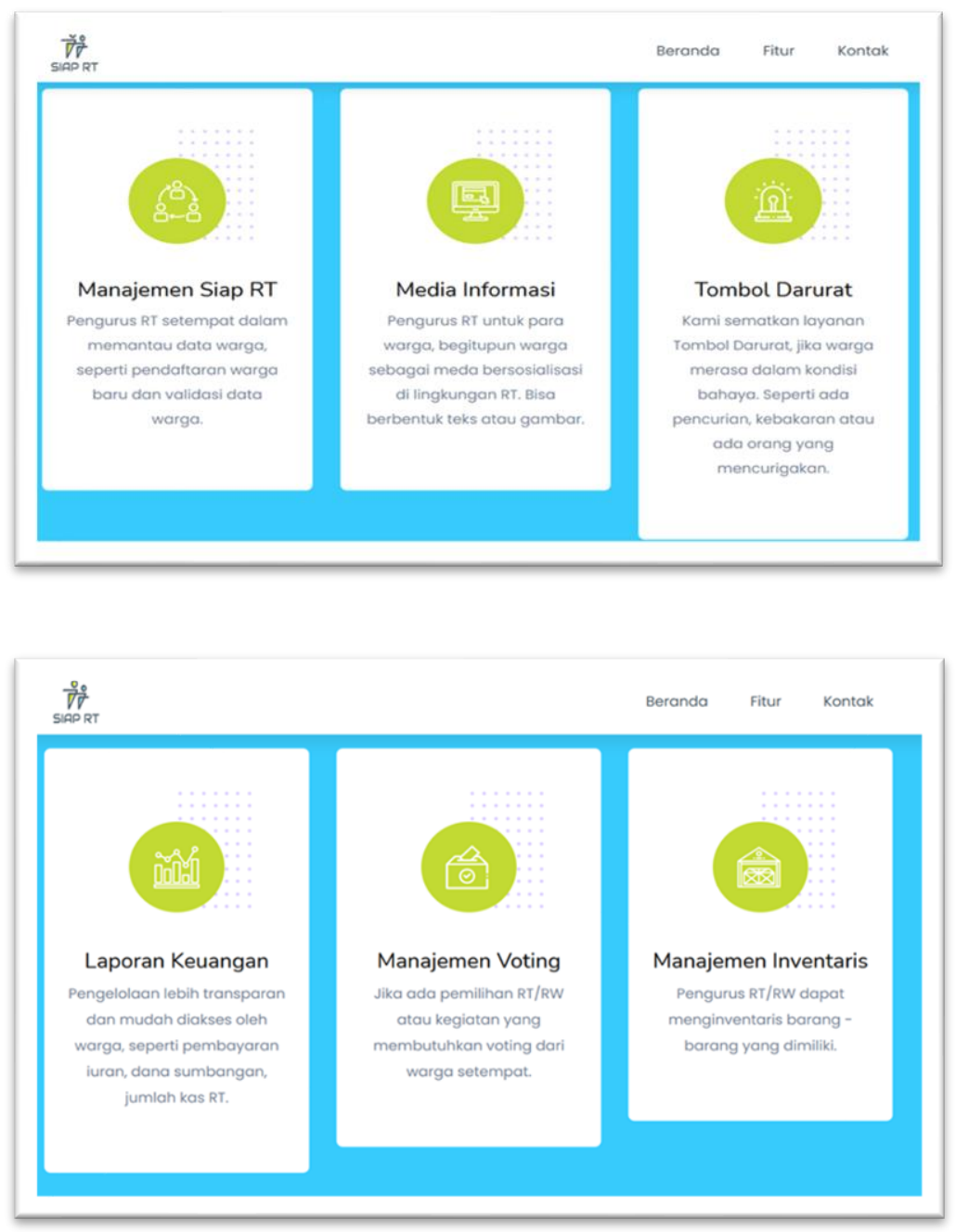

Gambar 1. Fitur-Fitur Aplikasi "Siap RT" 


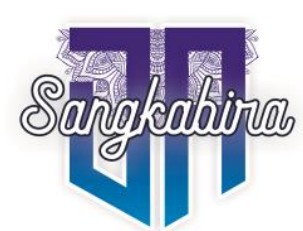

Vol. 2, No. 1, Desember 2021

Dengan melihat kondisi beberapa warga RT 01 dan 02 Kesra Tanjung Karang Permai yang secara usia sudah lanjut maka Tim pengabdi melakukan pendampingan secara berkelanjutan dan kebetulan salah satu tim pengabdi tinggal di lingkungan Kesra sehingga memudahkan untuk memberikan pendampingan secara terus menerus.

Tahap Evaluasi Kegiatan

Adapun pada tahap evaluasi kegiatan dilakukan pada bulan Oktober-November 2021. Hal-hal yang jadi tolak ukur pada tahap ini adalah sebagai berikut :

Tabel 1. Tolak Ukur Pelaksanaan

\begin{tabular}{|c|c|c|}
\hline Tujuan & Indikator Capaian & Tolak Ukur \\
\hline $\begin{array}{l}\text { Pembuatan modul/ template } \\
\text { cara penggunaan aplikasi } \\
\text { Siap RT baik untuk RT dan } \\
\text { warga untuk memudahkan } \\
\text { pengguna aplikasi ini }\end{array}$ & $\begin{array}{l}\text { Tim pengabdi bisa membuat } \\
\text { modul/template cara } \\
\text { penggunaan aplikasi Siap RT } \\
\text { yang mudah digunakan oleh } \\
\text { peserta dimana langkah- } \\
\text { langkahnya menggunakan } \\
\text { bahasa yang sederhana dan } \\
\text { jelas }\end{array}$ & $\begin{array}{l}\text { Peserta mampu } \\
\text { menggunakan aplikasi } \\
\text { siap RT ini dengan mudah } \\
\text { tanpa berpikir panjang }\end{array}$ \\
\hline $\begin{array}{l}\text { Melakukan pendampingan } \\
\text { agar ketua RT dan warga } \\
\text { lebih memahami aplikasi Siap } \\
\text { RT ini }\end{array}$ & $\begin{array}{l}\text { Peserta sudah bisa } \\
\text { menjalankan aplikasi Siap RT } \\
\text { dengan mencoba langkah- } \\
\text { langkah seperti yang ada di } \\
\text { modul dan mencoba menu- } \\
\text { menu yang ada disana. }\end{array}$ & $\begin{array}{l}\text { Peserta sudah } \\
\text { menggunakan aplikasi } \\
\text { Siap RT ini karena sudah } \\
\text { berulang-ulang kali } \\
\text { menggunakannya dan } \\
\text { kalaupun ketua RT diganti } \\
\text { tinggal menggunakan } \\
\text { template tersebut dengan } \\
\text { mudah }\end{array}$ \\
\hline $\begin{array}{l}\text { Agar Ketua RT dan warga } \\
\text { lebih mengerti dan mampu } \\
\text { mengaplikasikan aplikasi Siap } \\
\text { RT, sehingga dapat } \\
\text { memberikan manfaat bagi } \\
\text { ketua RT dan warga RT } \\
\text { tersebut }\end{array}$ & $\begin{array}{l}\text { Setelah peserta } \\
\text { menggunakan aplikasi siap } \\
\text { RT yang baik dan benar, bisa } \\
\text { membantu mempermudah } \\
\text { tugas-tugas rutin pengurus } \\
\text { rumah tangga (RT) dalam } \\
\text { menata administrasi warga } \\
\text { maupun keuangan sehingga } \\
\text { lebih transparan. Dari aplikasi } \\
\text { ini juga diharapkan dapat } \\
\text { memperat hubungan antar } \\
\text { warga, menumbuhkan rasa } \\
\text { persaudaraan antar warga, } \\
\text { saling mengenal, saling } \\
\text { peduli, dan saling berbagi } \\
\text { informasi dengan warga } \\
\text { sekitar khususnya tetangga } \\
\text { lingkungannya }\end{array}$ & $\begin{array}{l}\text { Peserta sudah bisa dengan } \\
\text { lancer menggunakan } \\
\text { aplikasi Siap RT }\end{array}$ \\
\hline
\end{tabular}




\section{Kesimpulan}

Ada beberapa hal yang bisa disimpulkan antara lain :

1. Melalui pendampingan ini diharapkan para peserta (Ketua RT dan warga) sudah bisa menggunakan aplikasi siap RT sehingga membantu mempermudah tugastugas rutin pengurus rumah tangga (RT) dalam menata administrasi warga maupun keuangan sehingga lebih transparan. Dari aplikasi ini juga diharapkan dapat memperat hubungan antar warga, menumbuhkan rasa persaudaraan antar warga, saling mengenal, saling peduli, dan saling berbagi informasi dengan warga sekitar khususnya tetangga lingkungannya

2. Ada beberapa faktor-faktor pendorong dan penghambat pelaksanaan pendampingan penggunaan aplikasi "siap RT" bagi ketua RT dan warga di lingkungan kersa, yaitu : : (a) faktor pendorong terdiri dari terjalinnya kerjasama antara tim pengabdian dengan ketua RT dan warga, selama pelaksanaan kegiatan pendampingan ini seluruh peserta memberikan apresiasi yang baik. Peserta secara aktif mengikuti kegiatan ini dari awal hingga akhir, hal ini ditunjukkan dengan banyaknya peserta yang bertanya. (b) faktor penghambat yaitu sulitnya menentukan jadwal pertemuan antara tim pengabdian dengan ketua RT dan warga karena kesibukan dalam menjalankan kegiatan sehari-hari mereka dan ditambah lagi di masa pendemi Covid-19 para peserta dan tim pengabdi agak takut melakukan pertemuan. Selain itu banyaknya warga yang lanjut usia sehingga pengajaran aplikasi ini cukup lama. Tetapi secara keseluruhan tidak ada hambatan yang terlalu teknis maupun administrative.

\section{Pengakuan/Acknowledgements}

Tim pengabdian mengucapkan terima kasih kepada seluruh peserta baik itu ketua RT 01 dan 02 beserta seluarh warga RT 01 dan 02 Lingkungan Kesra yang turut terlibat secara langsung atau tidak langsung dalam mensukseskan kegiatan program pengabdian masyarakat.

\section{Daftar Referensi}

Bariyyah \& Permatasari.D., (2017), Pelatihan Pemanfaatan Media Online dalam Layanan Bimbingan Konseling bagi Konselor Sekolah Menengah Pertama diKabupaten Pamekasan Madura.Jurnal Pengabdian kepada Masyarakat IKIP PGRI Jember, 1(1), 63-69.

Dwi Krisbiantoro, Dwi., Aziz Abdul dan Putranto, B. D (2019) Pendampingan Penggunaan Aplikasi Rt Online. Jurnal Pengabdian Dan Pemberdayaan Masyarakat LPIP UMP. ISSN: $2549-8347$ (Online), ISSN: 2579-9126 (Print) Volume 3 No. 2 September 2019 ISSN: 2549-8347 (Online), ISSN: 2579-9126 (Print) 